\title{
PENGGUNAAN MEDIA NITASAPURA UNTUK MENINGKATKAN AKTIVITAS DAN HASIL BELAJAR SISWA KELAS II SD NEGERI 6 DAUHWARU
}

\author{
Ni Luh Putu Yus Ani \\ SD Negeri 3 Pendem, Jalan Rajawali No 1 A Satria Kelurahan Pendem, Jembrana; \\ yus_ani@yahoo.com
}

\begin{abstract}
Abstrak. Penelitian tindakan kelas ini dilakukan dengan tujuan untuk meningkatkan aktivitas dan hasil belajar dengan menggunakan Media Nitasapura. Subjek penelitian ini yaitu siswa kelas II SD Negeri 6 Dauhwaru pada semester ganjil tahun pelajaran 2018/2019 sebanyak 34 orang. Data dikumpulkan dengan teknik observasi dan tes untuk memperoleh data aktivitas belajar dan data hasil belajar siswa. Data yang terkumpul dipaparkan secara kualitatif dengan teknik deskriptif komparatif. Penggunaan Media Nitasapura dalam pembelajaran matematika mampu meningkatkan aktivitas siswa dalam belajar matematika, dari kategori aktivitas belajar kurang aktif sebelum tindakan menjadi kategori aktivitas aktif pada akhir tindakan. Penggunaan Media Nitasapura dapat meningkatkan hasil belajar siswa kelas II SD Negeri 6 Dauhwaru pada materi bilangan. Hal tersebut dibuktikan dari rata-rata nilai tes siklus I adalah 66,6 kategori cukup dengan ketuntasan belajar 73,53\% sedangkan nilai rata-rata hasil tes pada siklus II adalah 82,4 kategori baik dengan ketuntasan belajar 100\%. Berdasarkan hasil tersebut dapat dikatakan bahwa penggunaan Media Nitasapura dalam pembelajaran matematika, dapat meningkatkan aktivitas dan hasil belajar siswa kelas II SD Negeri 6 Dauhwaru.
\end{abstract}

Kata Kunci: aktivitas, hasil belajar, media nitasapura

\section{THE USE OF NITASAPURA TO IMPROVE ACTIVITIES AND LEARNING ACHIEVEMENT OF THE SECOND GRADERS AT SD NEGERI 6 DAUHWARU}

\begin{abstract}
This study is a classroom action research aims to increase the activity and learning achievemen making use of Nitasapura. Subject of the study is the 34 first semester students of the second graders SD Negeri 6 Dauhwaru academic year 2018/2019. Technique of collecting data applied in this study is observation and test to obtain the data on students' learning activities and learning achievement. The collected data were presented qualitatively applying a comparative descriptive technique. The use of Nitasapura in mathematics teaching and learning may increase students' activities in learning mathematics; before the treatment it is at the category of less active learning, and it becomes an active category at the end of the treatment. The use of Nitasapura improves the students learning achievement of the second graders at SD Negeri 6 Dauhwaru for the topic of number. This fact can be observed from result of the first cycle average test score which is 66.6, it is in everage category with $73.53 \%$ learning achievement. Meanwhile, the average test score of the second cycle is 82.4, at good category with $100 \%$ learning achievement. Based on these facts, it is to say that the use of Nitasapura in mathematics teaching and learning increases the activities and learning achievement of the second graders at SD Negeri Dauhwaru 6.
\end{abstract}


Keywords: activity, learning results, Nitasapura

\section{Pendahuluan}

\subsection{Latar Belakang Masalah}

Matematika merupakan salah satu mata pelajaran yang mendukung perkembangan ilmu pengetahuan dan teknologi. Dengan demikian diperlukan kemampuan untuk memperoleh, mengelola, dan memanfaatkan ilmu pengetahuan dan teknologi tersebut secara proporsional. Kemampuan ini membutuhkan pemikiran yang sistematis, logis, dan kritis yang dapat dikembangkan melalui pembelajaran. Dalam kegiatan pembelajaran, telah ditentukan sebelumnya tujuan yang ingin dicapai, diantaranya adalah aktivitas dan hasil belajar. Dan apabila peserta didik dapat mencapai tujuan pembelajaran yang telah ditentukan sebeleum proses pembelajaran berlangsung maka peserta didik dinyatakan berhasil.

Berdasarkan data empiris untuk semester genap tahun pelajaran 2017/2018 hasil belajar matematika siswa Kelas II SD Negeri 6 Dauhwaru kurang memuaskan , rata-rata nilainya masih berada di bawah KKM $(6,00)$. Kurang memuaskannya hasil belajar siswa dalam bidang matematika dipengaruhi oleh berbagai faktor yang satu diantaranya adalah aktivitas siswa dalam mengikuti pelajaran matematika (Purwanto (2010:106-107)).

Aktivitas belajar yang berdampak pada hasil belajar siswa dipengaruhi oleh berbagai faktor yang terlibat langsung dan tidak langsung dalam proses pembelajaran. Faktor yang secara nyata dilakoni oleh guru yang dapat mempengaruhi kadar dan tingkat aktivitas serta hasil belajar siswa adalah cara guru menyajikan materi ajar atau media pembelajaran yang digunakan. Siswa kurang tertarik dan kurang perhatian terhadap pembelajaran yang disampaikan oleh guru. Siswa menganggap aktivitas pembelajaran matematika hanya duduk memperhatikan contoh soal dan penjelasan yang diberikan guru dilanjutkan dengan mengerjakan soal-soal yang ada di buku paket atau lembar latihan soal siswa. Salah satu cara mengajarkan agar siswa senang belajar matematika adalah dalam pembelajaran menggunakan media pembelajan yang menarik. Dengan menggunakan media pembelajaran yang menarik hal-hal yang abstrak dapat disajikan dalam bentuk konkrit/nyata yang dapat diamati dan dipegang sehingga mudah dipahami. Salah satu alternative media yang digunakan yaitu nitasapura. Media nitasapura adalah media yang dibuat dari triplek . Nitasapura merupakan akronim dari nilai tempat satuan puluhan dan ratusan. Dengan digunakan media nitasapura dapat meningkatkan aktivitas dan hasil belajar matematika pada materi bilangan khususnya dalam menentukan nilai tempat suatu bilangan.

\subsection{Rumusan Masalah}

Berdasarkan uraian diatas maka dapat dirumuskan permasalahan sebagai berikut:

1. Apakah pembelajaran nilai tempat bilangan dengan media nitasapura dapat meningkatkan aktivitas belajar siswa kelas II SD Negeri 6 Dauhwaru? 
2. Apakah pembelajaran nilai tempat bilangan dengan media nitasapura dapat meningkatkan hasil belajar siswa kelas II SD Negeri 6 Dauhwaru?

\subsection{Tujuan Penelitian}

Penelitian ini bertujuan untuk :

1. Mengetahui apakah pembelajaran nilai tempat bilangan dengan media nitasapura dapat meningkatkan aktivitas belajar siswa kelas II SD Negeri 6 Dauhwaru.

2. Mengetahui apakah pembelajaran nilai tempat bilangan dengan media nitasapura dapat meningkatkan hasil belajar siswa kelas II SD Negeri 6 Dauhwaru.

\subsection{Manfaat Hasil Penelitian}

Manfaat penelitian ini yaitu memperoleh pengalaman baru bagi siswa sehingga termotivasi untuk mengikuti pembelajaran berikutnya. Bagi guru penelitian ini dapat memperoleh pengalaman melakukan penelitian tindakan kelas dan memberikan masukan pada guru lain dalam penerapan penggunaan media pembelajaran yang inovatif, serta sebagai acuan bagi penelitian tindakan kelas selanjutnya. Bagi sekolah penelitian ini sebagai sumber referensi sehingga dapat meningkatkan mutu sekolah.

\section{Tinjauan Pustaka}

\subsection{Media Pembelajaran}

Kata media berasal dari bahasa Latin "medius" yang secara secara harfiah dapat diartikan sebagai perantara atau pengantar. Media dalam proses pembelajaran merujuk pada perantara atau pengantar pesan dari sumber ke penerima pesan. Dengan demikian merangsang pikiran, perasaan, perhatian dan kemauan sehingga terdorong serta terlibat dalam pembelajaran. Proses pembelajaran pada dasarnya juga merupakan proses komunikasi, sehingga media yang digunakan dalam pembelajaran disebut media pembelajaran. (Nurhidayati, 2014:2) Dalam proses pembelajaran, media berfungsi sebagai pembawa informasi dari sumber yaitu guru menuju penerima yaitu siswa. Sedangkan metode adalah prosedur untuk membantu siswa dalam menerima dan mengolah informasi guna mencapai tujuan pembelajaran (Santiyasa 2007:3). Selanjutnya, Gerlach \& Ely dalam Santiyasa (2007:4) menyebutkan tiga kelebihan penggunaan media pembelajaran dalam pembelajaran sebagai berikut, pertama, kemapuan fiksatif, artinya dapat menangkap, menyimpan, dan menampilkan kembali suatu obyek atau kejadian. Dengan kemampuan ini, obyek atau kejadian dapat digambar, dipotret, direkam, difilmkan, kemudian dapat disimpan dan pada saat diperlukan dapat ditunjukkan dan diamati kembali seperti kejadian aslinya. Kedua, kemampuan manipulatif, artinya media dapat menampilkan kembali obyek atau kejadian dengan berbagai macam perubahan (manipulasi) sesuai keperluan, misalnya diubah ukurannya, kecepatannya, warnanya, serta dapat pula diulang-ulang penyajiannya. Ketiga, kemampuan distributif, artinya media mampu menjangkau audien yang besar jumlahnya dalam satu kali penyajian secara serempak, misalnya siaran TV atau Radio.

Dari beberapa uraian pendapat di atas, disimpulkan bahwa proses pembelajaran berjalan dalam satu sistem yang membutuhkan komunikasi aktif dan efektif antara guru dengan 
siswa, sehingga media pembelajaran yang merupakan media komunikasi sangat dibutuhkan sebagai katalisator untuk mencapai tujuan pembelajaran itu sendiri. Tanpa adanya media pembelajaran, komunikasi dalam proses pembelajaran tidak berjalan optimal karena media pembelajaran saat ini telah menjadi komponen integral yang harus selalu ada pada setiap pembelajaran, bukan pada pembelajaran mata pelajaran tertentu saja.

\subsection{Media Nitasapura}

Media nitasapura merupakan modifikasi dari media kantong bilangan. Raharjo dalam Siti Zulaichah (2014) mengemukakan bahwa kantong bilangan merupakan media konkret berupa kantong-kantong yang diisi dengan lidi atau sedotan. Kantong-kantong tersebut ditempel pada sebuah bidang datar sesuai nilai tempat dan dapat digunakan untuk mencari hasil penjumlahan melalui peragaan. Penamaan media nitasapura merupakan akronim dari nilai tempat satuan puluhan dan ratusan. Media nitasapura dibuat dari triplek tipis yang dilengkapi tempat bilangan dari botol plastik bekas dan digunakan pipet sebagai angka yang ditunjukkan dalam nilai tempat tersebut. Media nitasapura berfungsi sebagai penentu nilai tempat suatu bilangan yaitu satuan, puluhan, dan ratusan. Manfaat penggunaan media nitasapura dalam pembelajaran yaitu (1) meningkatkan minat dan mendorong siswa lebih memperhatikan pelajaran sehingga dapat meningkatkan aktivitas belajar, (2) lebih memusatkan perhatian siswa, (3) memindahkan suatu pemikiran kedalam situasi yang nyata dan sesungguhnya. Dengan demikian media nitasapura dapat meningkatkan aktivitas dan hasil belajar siswa.

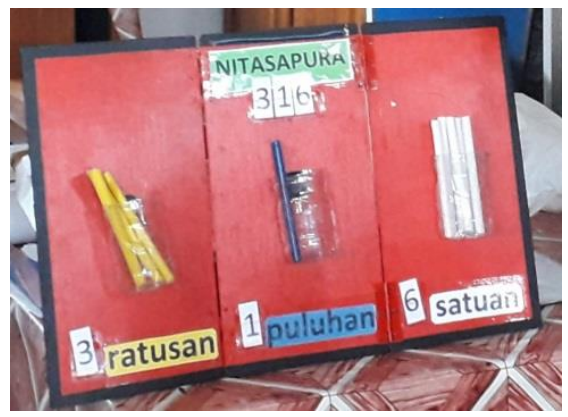

Gambar 2.1. Media nitasapura

\subsection{Aktivitas Belajar}

Pembelajaran yang efektif adalah pembelajaran yang menyediakan kesempatan belajar sendiri atau melakukan aktivitas sendiri. Proses pembelajaran yang dilakukan di dalam kelas merupakan aktivitas mentransformasikan pengetahuan, sikap, dan ketrampilan. Aktivitas belajar adalah aktivitas yang bersifat fisik maupun mental. Dalam proses belajar kedua aktivitas itu harus saling berkaitan. Lebih lanjut piaget menerangkan dalam buku Sardiman bahwa jika seorang anak berfikir tanpa berbuat sesuatu, berarti itu tidak berfikir (Sardiman, 2011:100). Aktivitas-aktivitas dalam belajar diantaranya melihat, mengamati, mendengarkan, menyimak, merasakan dan memahami sesuatu yang dipelajari. Dengan demikian berbagai aktivitas tersebut dapat dijadikan dasar dalam mengukur aktivitas siswa 
dalam belajar. Secara rinci aspek yang dijadikan acuan dalam mengamati aktivitas belajar siswa adalah siswa mengikuti proses pembelajaran, siswa melakukan diskusi dalam kelompoknya, siswa berusaha mencari informasi, siswa melakukan per tutoring, siswa bertanya dan menanggapi pertanyaan, siswa mampu berkomunikasi dengan guru, dan siswa dapat menyelesaikan tugas yang diberikan.

\subsection{Hasil Belajar}

Hasil belajar merupakan bagian terpenting dalam pembelajaran. Sudjana (2005: 3) mendefinisikan hasil belajar siswa pada hakikatnya adalah perubahan tingkah laku sebagai hasil belajar dalam pengertian yang lebih luas mencakup bidang kognitif, afektif, dan psikomotorik. Bila diintegrasikan ke dalam pembelajaran di kelas, hasil belajar dapat dijadikan sebagai bahan evaluasi bagi guru. Seperti yang dikemukakan Purwanto (2010:42) bahwa hasil belajar menunjukkan kemampuan siswa yang sebenarnya usai mengalami proses pengalihan ilmu pengetahuan dalam pembelajaran di kelas. Hasil belajar menjadi tolok ukur keberhasil siswa dan guru. Apabila nilai hasil belajar siswa tinggi, berarti pembelajaran yang dilakukan guru berhasil. Dimyati dan Mudjiono (2006: 3-4) juga menyebutkan hasil belajar merupakan hasil dari suatu interaksi tindak belajar dan tindak mengajar. Dari sisi guru, tindak mengajar diakhiri dengan proses evaluasi hasil belajar. Dari sisi siswa, hasil belajar merupakan berakhirnya pengajaran dari puncak proses belajar.

\subsection{Nilai Tempat Bilangan}

Nilai tempat suatu bilangan adalah nilai dari sebuah angka yang menunjukkan letaknya pada suatu bilangan. Nilai tempat dinyatakan dengan huruf yang berupa tulisan. Nilai tempat merupakan letak angka dalam bilangan. Misal: satuan, puluhan, dan ratusan. Susunan nilai tempat suatu bilangan yaitu:

Bilangan satuan disusun oleh satu angka, antara 0 sampai 9

Bilangan puluhan disusun oleh dua angka, antara 10 sampai 99

Bilangan ratusan disususun oleh tiga angka, antara 100 sampai 999

Menentukan nilai tempat suatu bilangan perhatikan contoh berikut ini.

\section{Bilangan 297}

Masing-masing angka pada lambang bilangan 297 mempunyai nilai tempat $2 \quad 9 \quad 7$

Angka 7 menduduki nilai tempat satuan

Angka 9 menduduki nilai tempat puluhan

Angka 2 menduduki nilai tempat ratusan

$297=2$ ratusan +9 puluhan +7 satuan

\subsection{Penelitian yang Relevan}

Beberapa penelitian yang menggunakan media sejenis nitasapura yaitu penelitian yang dilakukan oleh Ika Dwiyanti (2015) berjudul Peningkatan Hasil Belajar Matematika Materi Nilai Tempat Melalui Metode Bermain Dengan Menggunakan Media Kantong Bilangan Kelas II MIN Dalaman Tahun Pelajaran 2014/2015, yang menyebutkan bahwa hasil belajar siswa dapat meningkat, pada siklus I siswa yang tuntas berjumlah 8 siswa dengan persentase 
ketuntasan sebanyak 36,37\% dan siklus II siswa yang tuntas mencapai 20 siswa dengan persentase ketuntasan mencapai $90 \%$. Penelitian yang menggunakan media kantong bilangan juga dilakukan oleh Devi Ratnasari (2016) yang menyebutkan bahwa ada pengaruh penggunaan media kantong bilangan terhadap hasil belajar matematika siswa pada penjumlahan bilangan secara bersusun pada siswa kelas I SD N Prambanan Sleman.

\section{Metode penelitian}

\subsection{Jenis dan Subyek Penelitian}

Penelitian ini merupakan Penelitian Tindakan Kelas (PTK).Subjek penelitian ini adalah semua siswa kelas II SD Negeri 6 Dauhwaru tahun ajaran 2018/2019 yang berjumlah 34 orang.

\subsection{Teknik dan Instrumen Pengumpulan Data}

Data-data yang dikumpulkan meliputi data aktivitas belajar siswa dan hasil belajar siswa. Data tersebut diperoleh dari sumber datanya yakni siswa yang menjadi subjek penelitian. Teknik pengumpulan data dalam penelitian ini adalah observasi dan tes tulis.

Instrumen yang digunakan dalam penelitian ini adalah sebagai berikut:

a. Lembar Observasi Aktivitas Siswa

Instrumen penelitian ini disusun dan digunakan untuk menghimpun data mengenai aktivitas siswa selama proses pembelajaran matematika dengan media nitasapura. Aspek yang diobservasi adalah aktivitas dalam mengikuti proses pembelajaran, melakukan diskusi kelompok, bertanya pada teman/guru, berani menunjukkan nilai tempat pada media, kecepatan dan ketepatan menentukan nilai tempat, menanggapi pertanyaan teman/guru, mengemukakan pendapat, dan menyelesaikan tugas.

b. Lembar Tes Tertulis

Instrumen penelitian ini berupa soal-soal yang disusun dan digunakan untuk menghimpun data hasil belajar siswa terhadap materi pelajaran matematika.

\subsection{Teknik Analisis Data}

Data hasil observasi aktivitas belajar siswa dianalisis secara kualitatif diskriptif untuk memberikan gambaran pelaksanaan pembelajaran. Sementara untuk menentukan klasifikasi aktivitas siswa dalam belajar dan apresiasi hasil belajar siswa dalam topik yang sedang dibahas digunakan pedoman konversi berikut :

$$
\begin{array}{ll}
\bar{x}>M i+1,5 S D i & : \text { sangat baik/sangat aktif } \\
M i+0,5 S D i<\bar{x} \leq M i+1,5 S D i & : \text { baik/aktif } \\
M i-0,5 S D i<\bar{x} \leq M i+0,5 S D i & : \text { cukup } \\
M i-1,5 S D i<\bar{x} \leq M i-0,5 S D i & : \text { kurang/kurang aktif } \\
0<\bar{x} \leq M i-1,5 S D i & : \text { sangat kurang/tidak aktif }
\end{array}
$$


Dengan Mi adalah mean ideal dan SDi adalah standar deviasi ideal yang dihitung dengan menggunakan rumus (Dantes, 2012:25):

$$
\begin{aligned}
& M i=\frac{1}{2}(\text { skor maksimum ideal }- \text { skor minimumideal }) \\
& S D i=\frac{1}{6}(\text { skor maksimum ideal }+ \text { skor minimum ideal })
\end{aligned}
$$

Data hasil belajar siswa dianalisis secara kuantitatif untuk mengetahui ketuntasan belajar siswa. Ketuntasan siswa secara individu ditetapkan dengan berpedoman pada KKM SD mata pelajaran matematika yaitu 60. Sedangkan persentase ketuntasan siswa secara klasikal dapat dihitung dengan rumus:

$$
\text { Presentase ketuntasan klasikal }=\frac{\text { jumlah siswa yang tuntas }}{\text { jumlah siswa seluruhnya }} \times 100 \%
$$

\subsection{Indikator Keberhasilan}

Keseluruhan data yang terkumpul selanjutnya dipergunakan untuk menilai keberhasilan tindakan yang diberikan dengan indikator keberhasilan sebagai berikut :

1. Keaktifan belajar siswa dikatakan berhasil jika mencapai rata-rata keaktifan $\geq 15$ atau kriteria aktif dalam pembelajaran.

2. Keberhasilan penelitian ini dilihat dari hasil belajar siswa yaitu apabila siswa telah mencapai ketuntasan belajar minimal 85\% dari jumlah siswa, serta mencapai ketuntasan individu dengan nilai $\geq 60$ pada saat evaluasi yang akan dilihat pada hasil evaluasi.

\section{Hasil Penelitian dan Pembahasan}

\subsection{Hasil Penelitian}

Berdasarkan penelitian tindakan kelas yang dilaksanakan dalam 2 siklus, diperoleh hasil penelitian sebagai berikut:

a. Pada observasi awal,diperoleh data bahwa keaktifan siswa kurang aktif.

Dari 34 siswa kelas II ada 22 siswa yang kurang aktif, 12 siswa yang cukup aktif dan hanya 2 siswa yang aktif. Nilai rata-rata yang diperoleh hanya 9,97 katagori kurang aktif. Kekurang aktivan siswa terlihat pada saat mengikuti pembelajaran, belum mampu mengajukan pertanyaan maupun menanggapi pendapat teman. Siswa belum menujukkan keaktifan dalam menunjukkan nilai tempat ke depan kelas.

b. Siklus I

Dalam pembelajaran siklus I pada tahap perencanaan, guru menyusun RPP dan menentukan Kompetensi Dasar yaitu KD 3.1 Menjelaskan makna bilangan cacah dan menentukan lambangnya berdasarkan nilai tempat dengan menggunakan model konkret serta cara membacanya, KD 4.1 Membaca dan menyajikan bilangan cacah dan lambangnya berdasarkan nilai tempat dengan menggunakan model konkret. Indikator pencapaian 
kompetensi pada pembelajaran siklus I adalah menentukan nilai tempat suatu bilangan. Pada tahap pelaksanaan siswa dikelompokkan menjadi 7 kelompok. Masing-masing kelompok diberikan LK 1 tentang nilai tempat bilangan untuk didiskusikan. Guru memberikan penjelasan tentang susunan nilai tempat suatu bilangan. Bilangan satuan ditunjukkan dengan pipet warna putih, bilangan puluhan dengan pipet warna biru dan bilangan ratusan dengan pipet warna kuning. Setelah berdiskusi di dalam kelompok, masing-masing kelompok menunjukkan nilai tempat bilangan dengan menggunakan media nitasapura. Pada siklus I aktivitas siswa dalam penggunaan media nitasapura cukup aktif. Dari 34 siswa, ada 8 orang yang kurang aktif, 16 cukup aktif dan 10 orang siswa yang aktif. Nilai rata-rata 12,65 klasifikasi cukup aktif. Meskipun suasana pembelajaran cukup aktif tetapi beberapa anggota kelompok lebih condong bermain daripada melakukan diskusi tentang nilai tempat sehingga dalam ketepatan menentukan nilai tempat masih perlu dibimbing. Hasil belajar pada siklus I adalah 66,6 katagori cukup dengan ketuntasan belajar 73,53\%. Dari 34 siswa ada 9 orang yang tidak tuntas dan 25 orang tuntas.

\section{c. Siklus II}

Untuk perencanaan pembelajaran pada siklus II sama dengan kegiatan pada siklus I hanya memperbaiki dalam pembentukan kelompok berdasarkan dari hasil belajar siklus I dan dalam pelaksaan tindakan berbeda pada permasalahan yang diberikan pada siswa. Permasalahan yang diberikan dalam bentuk soal cerita. Soal cerita yang ada dalam LK 2 didiskusikan dalam kelompok kemudian menentukan bilangan yang dimaksud pada soal cerita. Setelah berdiskusi, masing-masing kelompok kembali menunjukkan nilai tempat bilangan tersebut pada media nitasapura. Pada siklus II siswa bekerja aktif dalam kelompoknya, dalam menunjukkan nilai tempat di depan kelas sudah berani dan tepat meletakkan nilai tempat tetapi masih ragu menjelaskan kepada temannya. Hasil observasi menunjukkan bahwa dari 34 siswa, 1 siswa yang kurang aktif, 7 siswa cukup aktif, 15 siswa yang aktif dan 1 siswa sangat aktif. Nilai rata-rata aktivitas pada siklus II adalah 16,15 klasifikasi aktif. Hasil belajar pada siklus II adalah 82,4 katagori baik dengan ketuntasan belajar $100 \%$.

Tabel 4.1. Rekapitulasi Aktivitas Siswa

\begin{tabular}{|c|l|l|l|}
\hline No & \multicolumn{1}{|c|}{ Observasi } & \multicolumn{1}{|c|}{ Rata-Rata } & \multicolumn{1}{c|}{ Klasifikasi } \\
\hline 1 & Tahap awal & 9,97 & Kurang Aktif \\
\hline 2 & Siklus I & 12,65 & Cukup Aktif \\
\hline 3 & Siklus II & 16,15 & Aktif \\
\hline
\end{tabular}

Tabel 4.2. Rekapitulasi Hasil Belajar Siswa

\begin{tabular}{|c|l|l|l|}
\hline No & \multicolumn{1}{|c|}{ Observasi } & \multicolumn{1}{|c|}{ Rata-Rata } & \multicolumn{1}{|c|}{ Ketuntasan } \\
\hline 1 & Siklus I & 66,6 & $73,53 \%$ \\
\hline 2 & Siklus II & 82,4 & $100 \%$ \\
\hline
\end{tabular}




\subsection{Pembahasan}

Berdasarkan hasil analisis data sebagaimana dalam Tabel 1 di atas dapat dikatakan bahwa penggunaan media nitasapura dapat meningkatkan aktivitas belajar siswa dalam mengikuti pelajaran matematika. Dari hasil tes siklus I dan siklus II diperoleh rata-rata skor siswa kelas II dari 66,6 dengan klasifikasi cukup menjadi 82,6 dengan klasifikasi Baik. Pada siklus II mulai ada tanda-tanda perubahan dalam diri siswa kearah perbaikan. Hal ini, karena siswa mulai dapat menikmati pembelajaran dengan menggunakan media. Peningkatan aktivitas belajar siswa dalam hal ini dapat dipahami mengingat bahwa secara teoritis semakin sering siswa melakukan aktivitas dan menghasilkan hasil yang positif dan diberikan reward sepantasnya akan menambah kepercayaan diri siswa untuk terus meningkatkan aktivitas belajarnya. Fenomena ini menjadi kunci untuk mencegah pembelajar dari kebosanan dan kepasifan yaitu mendesain kegiatan belajar yang memungkinkan mereka benar-benar melihat adanya penghargaan terhadap apa yang telah dilakukannya.Hal inilah yang terus dibina dan dipelihara dalam setiap siklus dengan tujuan mempertahankan sesuatu yang telah baik dan meningkatkan aktivitas siswa yang kurang aktif.

Hal tersebut juga menunjukkan bahwa penggunaan media nitasapura dalam pembelajaran matematika dapat meningkatkan hasil belajar siswa yang dapat dilihat dari peningkatan ketuntasan belajar secara klasikal. Pada siklus I ketuntasan belajar hanya 73,53\% dan pada siklus II meningkat menjadi $100 \%$. Kondisi ini sangat diharapkan karena menurut teori pembelajaran matematika realistik, ketika siswa diberikan kondisi pembelajaran nyata (relatif nyata) maka siswa akan memiliki keyakinan yang lebih besar untuk mempelajari lebih jauh. Kondisi ini jika terus berlangsung akan berdampak pada peningkatan proses belajar dan pada akhirnya akan ditunjukkan dengan prestasi belajar. Kemampuan menyelesaikan tes di kalangan siswa, juga mulai menunjukkan peningkatan. Hal ini juga menunjukkan bahwa siswa telah termotivasi dengan media pembelajaran nitasapura, karena pencapaian sesungguhnya merupakan puncak dari keberhasilan menggunakan media nitasapura. Kondisi ini dapat dijadikan indikator bahwa telah ada peningkatan hasil belajar Matematika pada siswa kelas II dengan menggunakan media nitasapura. Dengan demikian berdasarkan kriteria atau indikator keberhasilan yang telah ditetapkan, dapat dikatakan bahwa pembelajaran matematika dengan menggunakan media nitasapura dapat meningkatan aktivitas belajar dan hasil belajar siswa.

\section{Kesimpulan dan Saran}

\subsection{Kesimpulan}

Berdasarkan hasil penelitian dan pembahasan, dapat disimpulkan:

1. Penggunaan media nitasapura dalam pembelajaran matematika mampu meningkatkan aktivitas siswa dalam belajar matematika, dari kategori aktivitas belajar kurang aktif sebelum tindakan menjadi kategori aktivitas aktif pada akhir tindakan.

2. Penggunaan media nitasapura dapat meningkatkan hasil belajar siswa kelas II SD Negeri 6 Dauhwaru. Hal tersebut nampak dari rata-rata nilai tes siklus I adalah 66,6 kategori 
cukup dengan ketuntasan belajar 73,53\% sedangkan nilai rata-rata hasil tes pada siklus II adalah 82,4 kategori baik dengan ketuntasan belajar $100 \%$.

\subsection{Saran}

Terkait dengan hasil yang diperoleh melalui tindakan berupa penggunan media nitasapura, saran yang perlu disampaikan adalah agar setiap guru, dalam proses pembelajarannya lebih kreatif dan mampu menggunakan media yang cocok dalam pembelajarannya, sehingga peserta didik tertarik pada pembelajaran yang dilaksanakan dan termotivasi untuk lebih memahami materi yang disampaikan, yang pada akhirnya akan mencapai hasil pembelajaran yang optimal. Peneliti menyaran agar guru mampu mengembangkan media pembelajaran yang baik, sesuai serta menarik bagi peserta didik. Sehingga peserta didik akan selalu senang mengikuti pembelajaran yang dilakasanakan.

\section{Daftar Pustaka}

Dantes, N. 2012. Metodologi Penelitian. Materi Kuliah. Singaraja: Undiksha Singaraja.

Devi Ratnasari. 2016. Pengaruh Penggunaan Media Kantong Bilangan Terhadap Hasil Belajar Matematika Penjumlahan Bilangan Secara Bersusun Pada Siswa Kelas I SD N Prambanan Sleman

Dimyati dan Mudjiono. 2006. Belajar dan Pembelajaran.Jakarta: PT. Rineka Cipta

Ika Dwi Yanti. 2015. Peningkatan Hasil Belajar Matematika Materi Nilai Tempat Melalui Metode Bermain Dengan Media Kantong Bilangan Kelas II MIN Dalaman Tahun Pelajaran 2014/2015

Nurhidayati. 2014. Hakikat Media Pembelajaran. http://staffnew.uny.ac.id/upload/132296142/pendidikan/MEDIA+PEMBELAJA RAN.pdf. Diakses, 10 September 2018

Purwanto. 2010. Evaluasi Hasil Belajar. Yogyakarta: Pustaka Belajar.

Santiyasa. 2007. Landasan Konseptual Media Pembelajaran, Makalah. Bali: Universitas Pendidikan Ganesha.

Sardiman, A.M. 2011. Interaksi dan Motivasi Belajar Mengajar. Jakarta: Rajawali

Siti Zulaichah. 2014. Efektivitas Penggunaan Media Kantong Bilangan untuk Meningkatkan Prestasi Belajar Matematika pada Anak Berkesulitan Belajar Matematika Kelas III. S1 Thesis. UNY

Sudjana. 2005. Dasar-Dasar Proses Belajar Mengajar. Bandung : Sinar Baru

\section{How to Cite:}

Ani, N.L.P.Y., (2019). Penggunaan media nitasapura untuk meningkatkan aktivitas dan hasil belajar siswa kelas II SD Negeri 6 Dauhwaru. IDEAL MATHEDU: Indonesian Digital Journal of Mathematics and Education, 6(1), 620-629. 